\title{
It's Tea Time, but What Flavor? Regional Variation in Sources of Support for the Tea Party Movement
}

\author{
Stacy G. Ulbig and Sarah Macha
}

While the Tea Party movement has gained much support and media attention over the past several years, the debate remains about the sources of support for the movement. Some argue that supporters are drawn to the movement by concerns about the state of the U.S. economy. Others believe the movement attracts those who are most disgruntled with the size and direction of the national government. Further, charges of racism and anti-immigrant attitudes among movement supporters continue to arise. Finally, some wonder what role moral issues play in this movement, if any. We believe that much of this debate results from the varied attraction of the Tea Party movement across the nation. Using data from a June 2010 nationwide USA Today/Gallup Poll, investigate the sources of movement support, finding that the basis of support varies by geographic region. We find that traditional, moral values, and counter to much popular sentiment, racism play no role in movement support in any region of the nation. Instead, concerns about illegal immigration, the economy, and the size of federal government predict movement support, but vary by region.

"Supporters have hailed [the movement] as a return to core American values; opponents have seen it as a racist, reactionary, and ultimately futile protest against the emerging reality of a multicultural, multiracial United States and a new era of government activism” (Mead 2011).

The Tea Party movement has been called one of the most "derided . . . minimized . . . and disrespected movements in American history. Yet, despite being systematically ignored, belittled, marginalized, and ostracized by political, academic, and media elites, the Tea Party movement has grown stronger and stronger" (Rasmussen 2010, 4; see also Harris 2010; Parker 2010). While the Tea Party movement garnered much support and media attention over the past several years, debate rages about the sources of support for the Tea Party. Some argue that supporters are drawn to the movement by concerns about the state of the U.S. economy. Others believe the movement attracts those who are most disgruntled with the size and direction of the national government. Further, charges of racism and anti-immigrant attitudes among movement supporters continue to arise. Finally, some wonder what role moral issues that have been so prominent in national politics for more than a decade play in this movement, if any.

Stacy G. Ulbig is Associate Professor of Political Science at Sam Houston State University. SARA MACHA is a graduate student in the Department of Political Science at Sam Houston State University.

The American Review of Politics, Vol. 33, Summer, 2012: 95-121

(C)2012 The American Review of Politics 
We believe that much of this debate results from the varied attraction of the Tea Party movement across the nation. While supporters in one region might be drawn to the Tea Party movement by economic or size of government concerns, supporters in other areas are likely drawn to the movement by concerns more particular to their region. Using data from a June 2010 nationwide USA Today/Gallup Poll, we investigate the sources of Tea Party support, with a particular eye toward whether the basis of support varies by geographic region. We find that neither moral issues nor, counter to much popular sentiment, racism play a role in movement support. We do find that economic concerns, anti-government sentiment, and views about illegal immigration play important, but varied roles in movement support across the nation. Viewing illegal immigration as a threat to the nation increases support for the Tea Party movement, but only in the West. Economic concerns are the key factor increasing movement support in the East, while antigovernment sentiment boosts support in the Midwest and both play key roles in the South where anti-government sentiment drives support more than economic concerns.

\section{The Origins of Third Party Support}

Though the Tea Party movement has neither fielded nor seated candidates under its own label, and thus does not yet meet most commonly accepted definitions of a true political party (see e.g., Downs 1957; Schlesinger 1994), research on the rise and fall of third parties in American sheds light on the origins of Tea Party movement support. ${ }^{1}$ Many argue that third party candidates and movements find the roots of their support in the "significant failure of the two major parties to meet a meaningful social or policy problem” (Stone and Rapaport 2001, 51; see also Mazmanian 1974; Rosenstone et al. 1996). The "push/pull" model of third party support argues that voters are attracted to third party movements by being pushed away from the existing major parties and pulled toward newly emergent third party movements and their candidates (Stone and Rapaport 2005). Support for movements like the Tea Party typically arises from a combination of the pull of the movement's issue positions and priorities, and the push away from the major parties because of dissatisfaction with their priorities, issue positions, and performance (Gold 1995; McCann, Rapaport and Stone 1999; Mazmanian 1974; Rosenstone et al. 1996; Stone and Rapaport 2001).

This "push-pull" theory of third parties explains not only the rise of such movements, but also their decline. Once a third party movement or candidate gains significant support, one of the two major parties usually reacts by adjusting their platform and/or rhetoric to co-opt the third party's issue priorities and positions (Beck 1979; Burnham 1970; Mazmanian 1974; 
Sundquist 1983). The major party's realignment frequently pulls voters back into the partisan fold, effectively destroying third party momentum. Such has been the fate of some of the strongest third party showings in American political history. The Populist Party faded after Democrats co-opted the silver issue (Hirano and Snyder 2007). The Reform Party movement faded once the Republicans moved to focus on "issues of a balanced federal budget, governmental reform, and limiting American commitment to internationalism" (Stone and Rapaport 2001, 52). And "the large and seemingly permanent decline in left-oriented third-party voting was linked to the large and sustained leftward shift of the Democratic Party following the New Deal” (Hirano and Snyder 2007, 3).

Applying the push-pull dynamic of third party support to the rise of the Tea Party movement allows us to better understand the factors motivating many to become Tea Partiers. The Republican Party likely birthed the Tea Party movement by shifting its priority and rhetoric from economic issues to moral/evangelical appeals. The contemporary Tea Party movement has its ideological roots in the fiscal conservative principles first articulated politically on the national stage by Barry Goldwater in his presidential campaign of 1964 (Rasmussen and Schoen 2010), and embraced by the Republican Party in the decades that followed. In the 1980s, Ronald Reagan ushered in a period of limited government and fiscal conservatism, but signs of dissent within the party became evident with Pat Robertson's bid for the party's presidential nomination in 1988. "Robertson's credentials were not explicitly tied to the political experience in the Republican Party, nor did he appeal to a traditional core constituency within the party" (Pastor et al. 1999, 424; see also Green and Guth 1988; Hertzke 1993; Oldfield 1995). His candidacy pulled a new set of voters into the Republican Party who were much more likely to call themselves "born-again Christians, fundamentalist in their orientation, and very religious" and to focus on the issues of school prayer and abortion (Pastor et al. 1999, 429). Importantly, these voters remained loyal to the Republican Party after Robertson failed to gain the party's nomination, throwing their support behind the eventual nominee, George H.W. Bush.

Under Bush's leadership, the Reagan-era priorities of fiscal conservatism and limited government faltered as the party increasingly appealed to and attracted voters on moral-values issues. Throughout the 1990s and early into the 2000s, as cultural issues came to dominate the Republican rhetoric (Kaufmann 2002), the party's candidate relied on religiously laden appeals to attract evangelical voters (Calfano and Djupe 2009). By 1992, Republican identifiers were much more likely than Democrats or Independents to see the moral decay of society and morality issues, more generally, as the most important problem facing the nation (Miller and Klobucar 2008), and the 
issue of abortion was pulling pro-life Democrats into the Republican fold (Killian and Wilcox 2008). The growing rift within the Republican Party allowed wealthy outsider Ross Perot to attract Republican voters who were disgruntled by the party's increasing focus on moral values issues in his failed but strong showing as a third party candidate in the presidential election of 1992. Perot supporters, as opposed to other voters, had more cynicism toward government and were more likely to believe that government wastes taxpayer money (Koch 1998). Indeed many Perot supporters were fiscal conservatives and libertarians who felt the Republican Party had swayed too far to the right on social issues (Rasmussen and Schoen 2010). Though the party moved to recapture many of these angry voters with its 1994 Contract with America, the internal division festered. Many within the party voiced concern over the growing government deficit (Miller and Klobucar 2003), yet between 2000 and 2004, Republican Party identification grew most strongly among evangelical Protestants (Winneg and Jamieson 2005). By the time Rick Santelli declared his desire to see a Tea Party movement form (McGrath 2010), it appeared that the Roberson campaign had indeed become a "bitter one, pitting a small group of intense, religious 'purists' against a mass of equally hostile 'professional' moderates" within the party (Green and Guth 1988, 161).

\section{What Drives a Tea Partier?}

It would appear, then, that Tea Party movement supporters are likely pulled to the movement because both the Republican and Democrat parties are pushing them away. But the source of movement supporters' dissent from the major parties is less clear. The scant academic research available offers a number of differing contentions about the attraction of the Tea Party movement, ranging from libertarian concerns for smaller government and lower taxes to fears about societal changes along racial and ethnic lines. Interestingly, the moral "family values" that have come to characterize much contemporary political debate are largely missing from the litany of causes cited for the rise of the Tea Party movement.

There is some common agreement that the movement appeals to those holding a healthy libertarian ideology, drawing heavily among anti-taxation and smaller government proponents. Spurred by economic crisis, most Tea Party supporters identify reducing the size of the federal government and lowering the deficit as important national priorities (Courser 2010), and this "passionate resistance to governmental taxation and regulation" (Tilden 2011, 214) serves to unite them behind the Tea Party label. At the same time, movement supporters express a strong distrust or lack of confidence in the government's ability to handle the nation's problems (Courser 2010). 
Taken together, these sentiments lead some to describe the Tea Party movement as a libertarian and anti-establishment organization that views hardworking and average American people to be those most affected by the unfortunate turn of economic events (see Cunningham 2010).

At the same time, many see the movement playing into racial and ethnic fears caused by rapidly changing national demographics. Paranoia, fear, and phobic racism have been cited as themes in the contemporary populism espoused by the movement (Fraser and Freeman 2010; Tilden 2011), with some seeing support springing mostly from those with a fear "of change, fear of decline, fear of strangers and an unfamiliar world" (Cunningham 2010, 24). Typically these fears are cast in terms of age-old racial tensions, with the predominantly White middle class and working class (Berlet 2011) cast as expressing "a visceral anger at the cultural and, to some extent, political eclipse of an America in which people who looked and thought like them were dominant" (Fraser and Freeman 2010, 81). Though less prominent, there is also some evidence that anti-immigrant attitudes may be part of this fear as well (Fraser and Freeman 2010), with Tea Party supporters' scapegoating of immigrants, as well as people of color (Bertlet 2011) to further their cause. It is perhaps no surprise, then, that some would claim that the movement is comprised of "a range of right-wing fringe and hate groups, including white supremacists [and] xenophobes” (Tilden 2011, 214).

While little agreement about the core causes of movement support emerges, the literature holds the common theme that the movement represents a very incoherent one with no single actor or group able to claim the national leadership of the "party" (Courser 2010). Without a consistent ideology, coherent set of policies, or common core set of beliefs (Harris 2010; Tilden 2011), many view the Tea Party movement as nothing more than "an amorphous collection of individuals and groups" (Mead 2011). Those seeking to identify clear policy stances from the group have been stymied by debates between prominent leaders in the movement (Baker 2010; Mead 2011; O’Rourke 2010). It is little wonder, then, that many see the movement as "a house of contradiction, a bewildering network of crosscutting political emotions, ideas, and institutions" (Fraser and Freeman 2010, 75).

Yet it is precisely this nationwide diversity that we believe helps explain the many contradictory claims about the sources of support for the Tea Party movement. As seemingly contradictory as the movement itself, we believe it is possible that no one is correct and yet everyone is correct. We suspect that while moral values probably play little role in the movement's momentum, economic concerns, anti-government sentiment, racial fears and anti-immigrant attitudes all play some role. Importantly, however, the impact of these different factors will vary across the nation. As many have 
argued, important regional variations in political culture, policy, and voter behavior exist across the nation (see e.g., Bullock et al. 2006; Elazar 1966; Erikson et al. 1993; Lieske 1993). Since the Tea Party movement seeks to appeal to those most disgruntled within the existing political parties, the factor that will be most important in drawing supporters will depend on the context within which voters find themselves. Tea Party movements in regions with a history of racial strife are likely to appeal strongly to those holding more racist attitudes, while those facing the pressing problem of illegal immigration are likely to poll well among those with strong antiimmigrant sentiments. Similarly, movements in parts of the nation hit hardest by the failing economy are likely to draw heavily from those with economic concerns and those in areas with a history of conservative fiscal policy are likely to find a home with those holding strong anti-government sentiments. In any region, however, those driven by traditional "family values" issues are not like to be drawn to the movement since they can readily find a home in the existing Republican party.

We therefore expect traditional, moral values to play little, if any role, in boosting support for the Tea Party movement in any part of the nation. Further, we expect that economic concerns, anti-government sentiment, racial attitudes, and feelings about illegal immigration to be important but for the impact of these factors to vary across the United States. While economic and anti-government sentiments are likely to drive support for the movement in multiple regions of the country (especially the Eastern and Midwestern regions) racial attitudes are more likely to be linked to Tea Party movement support in the South and concerns over immigration are likely to be tied more closely to support in the Western region.

\section{Data and Measures}

To investigate regional variations in the sources of Tea Party movement support, we employ data from a June 2010 USA Today/Gallup Poll. ${ }^{2}$ The study interviewed a random sample of 1,014 adult American citizens about a range of political topics, including support for the Tea Party movement in America. Respondents were coded as residing in one of four U.S. Census Bureau regions-East (New England and Mid-Atlantic states), Midwest (East Central and West Central states), South (states of the former Confederacy and border South states), or West (Rocky Mountain and Pacific coast states). ${ }^{3}$

We take support for the Tea Party movement as our key dependent variable, and code support as a dichotomous variable (1=supporter; $0=$ nonsupporter). Respondents were asked whether they considered themselves to be "a supporter of the Tea Party movement," "an opponent of the Tea Party 
movement," or neither. Nationwide a little more than one-third of those interviewed (37.2\%) report being supporters of the movement, while more than half (56.3\%) said they are not supporters, claiming to be either opponents or neither supporters nor opponents. ${ }^{4}$ Further, there is some minor regional variation in movement support, with support being the highest in the South and the lowest in the East. (See Table 1 for question wording and coding, as well as basic descriptive statistics of all variables.)

We predict support for the Tea Party movement with feelings about the U.S. economy and the U.S. government, issues stances on traditional/moral values and illegal immigration, and attitudes toward racial minorities. Feelings about the U.S. economy are measured with a question asking respondents to identify the "most important problem facing this country today." Respondents were encouraged to give up to three responses. Our measure is the number of responses each respondent gave related to the economy. Thus, this measure ranges from 0 to 3, with a nationwide mean of just less than one mention of the economy as the most important problem. As Table 1 illustrates, concerns about the economy are widespread with more than half of respondents in each region mentioning the economy as a problem at least once. Still, those in the East seem to be more concerned than others. Slightly more than two-thirds of respondents in the Eastern region (67.1\%) mention the economy as a problem at least once while those in the other regions report lower levels of concern.

Anti-government sentiment is captured with a single, dichotomous item asking respondents whether they believe that "the federal government is more part of the problem" (coded 1) or "more a part of the solution" (coded 0 ) when it comes to the "issues facing the country today." Nationwide, nearly two-thirds of Americans (65.9\%) report the federal government to be more a part of the problem than the solution. ${ }^{6}$ Southerners report the highest level of anti-government sentiment, 69.2 percent of Southern respondents view the federal government as problematic. ${ }^{7}$

Views on traditional/moral values were tapped with a single question about whether the "government should promote traditional values" or "should not favor any set of values." We use a dichotomous measure, with the 47.2 percent of Americans believing the government should promote traditional values coded 1 and the 49.8 percent reporting that the government should not favor any set of values or reporting mixed attitudes coded $0 .{ }^{8}$ Not surprisingly, those living in the Midwest and South report the highest levels of support for governmental promotion of traditional values, with more than half of the respondents in each of these regions feeling the government should promote such values.

Issue stances on illegal immigration were gauged with a question about "how serious a threat" the respondent felt illegal immigration was "to the 


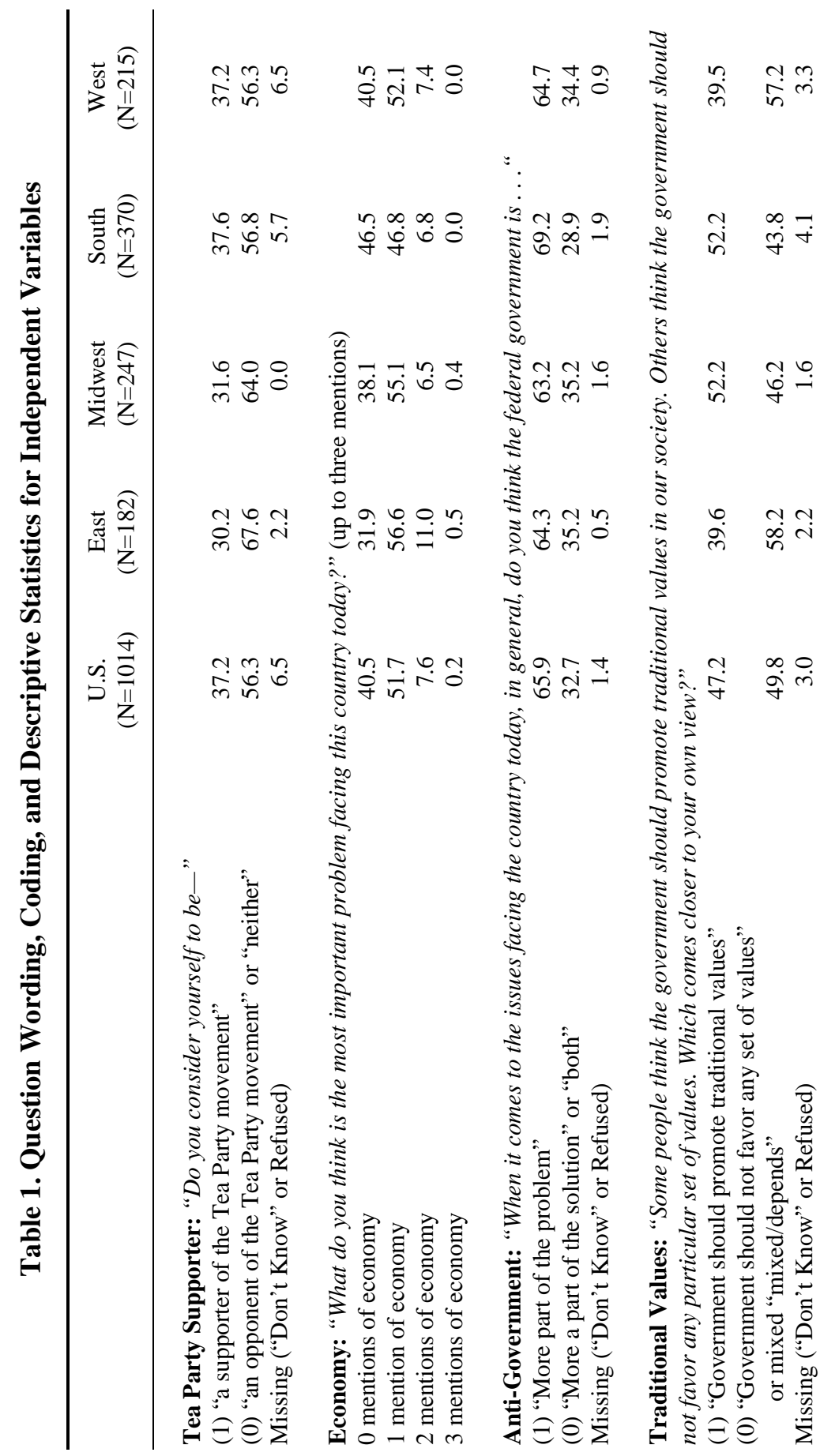




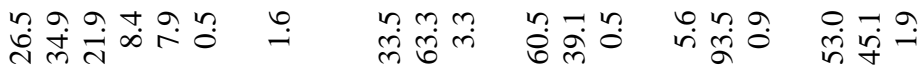

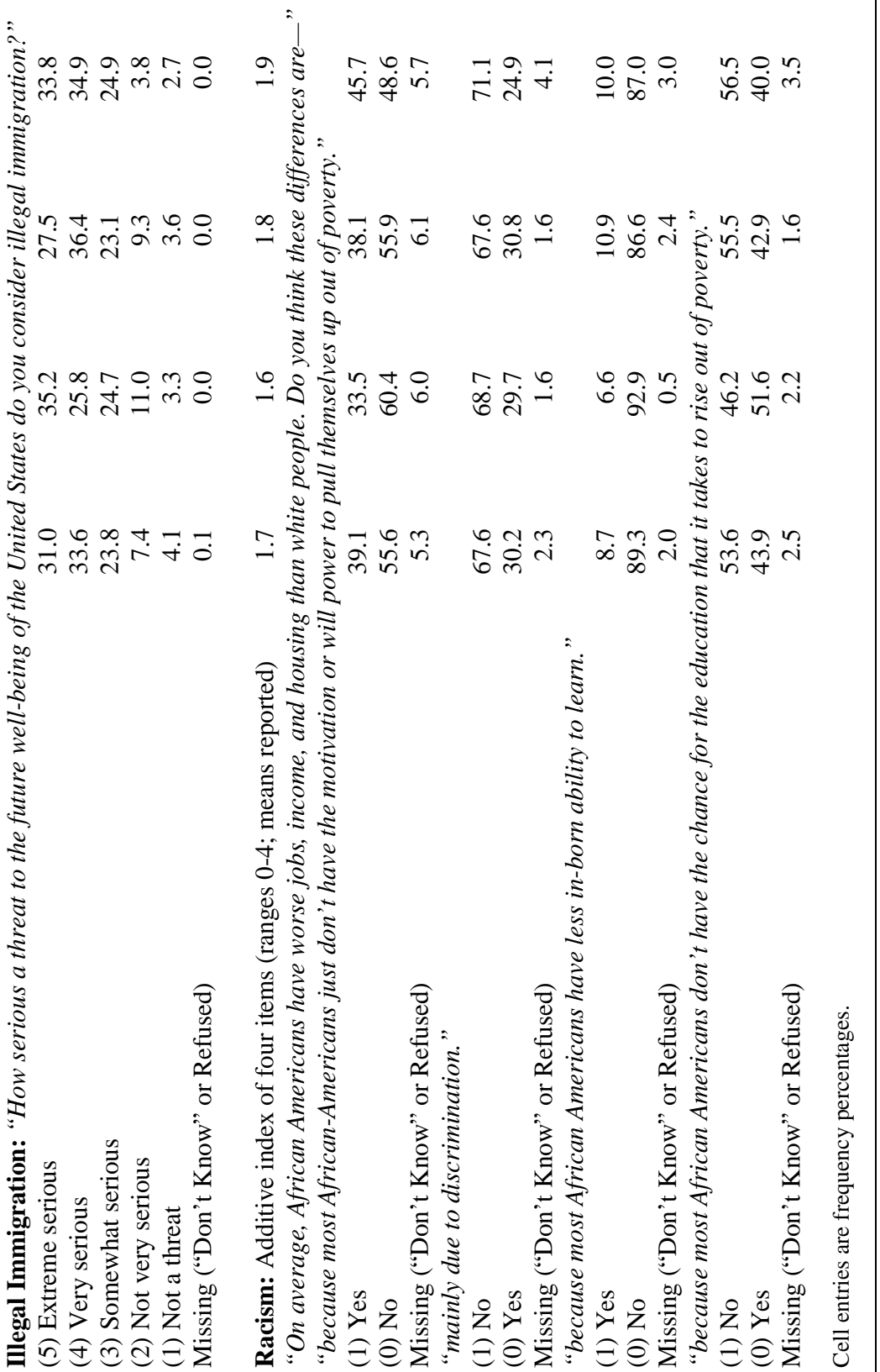


future well being of the United States." Respondents were asked to place themselves on a five-point scale, ranging from one, "not a serious threat," to five, "an extremely serious threat." Nationwide, the mean threat level reported was 3.8 on the five-point scale. Interestingly, there is remarkably little variation across the regions, with average threat ratings ranging from 3.6 in the West to 3.9 in the South. ${ }^{9}$

Racial attitudes were measured with a four-item additive index asking respondents whether they felt African-Americans have worse jobs, income, and housing than white people (a) "because most African-Americans just don't have the motivation or will power to pull themselves up out of poverty," (b) "mainly due to discrimination," (c) "because most African-Americans have less in-born ability to learn," and (d) "because most AfricanAmericans don't have the chance for the education that it takes to rise out of poverty." 10 Responses to each item were coded dichotomously, with more racially resentful sentiments coded one (i.e., agreement with the first and third statements and disagreement with the second and fourth) and less resentful statements coded as zero. Despite the many gains made in race relations in this nation, there is still some evidence of racial resentment. Nationwide, respondents agreed with 1.7 of the racially resentful statements. As we might expect, Southerners expressed slightly higher levels of racial resentment (with a mean of 1.9 statements), while those in the East and West report the lowest levels (with 1.6 statements).

\section{Analysis and Findings}

To explore the varied relationship between each of these factors and support for the Tea Party movement, we perform a series of multivariate regression analyses. Given the dichotomous nature of our dependent variable ( 1 =supporter of movement; $0=$ non-supporter), we employ probit regression. Additionally, we include controls for a number of demographic variables thought to have an impact on movement support, including respondent's sex, race, income, marital status, education level, partisanship, and ideology. ${ }^{11}$ We expect that male, Anglo, married, wealthier, more educated, conservative, Republican respondents will be more likely to express support for the movement. ${ }^{12}$

As the results presented on Table 2 illustrate, traditional values do not appear to be linked to support for the Tea Party movement in any part of the nation. Thus, as we expected, support for the movement has little to do with the promotion of such values. In fact, notwithstanding statistical significance, the negative coefficients for the traditional values measure in the East and Midwest models, as well as the overall model, suggest that those who support government promotion of traditional values are less likely to support 
Table 2. Impact of Various Factors on Tea Party Support

\begin{tabular}{|c|c|c|c|c|c|}
\hline & U.S. & East & Midwest & South & West \\
\hline Economy & $\begin{array}{c}0.202 * \\
(0.091)\end{array}$ & $\begin{array}{c}0.614^{*} \\
(0.277)\end{array}$ & $\begin{array}{c}0.032 \\
(0.178)\end{array}$ & $\begin{array}{c}0.329 * \\
(0.151)\end{array}$ & $\begin{array}{c}0.084 \\
(0.258)\end{array}$ \\
\hline Anti-Government & $\begin{array}{c}0.811^{* *} \\
(0.153)\end{array}$ & $\begin{array}{c}0.628 \\
(0.455)\end{array}$ & $\begin{array}{l}1.047^{* *} \\
(0.284)\end{array}$ & $\begin{array}{c}0.884^{* *} \\
(0.266)\end{array}$ & $\begin{array}{c}0.503 \\
(0.449)\end{array}$ \\
\hline Traditional Values & $\begin{array}{l}-0.083 \\
(0.118)\end{array}$ & $\begin{array}{l}-0.285 \\
(0.335)\end{array}$ & $\begin{array}{l}-0.169 \\
(0.242)\end{array}$ & $\begin{array}{c}0.010 \\
(0.201)\end{array}$ & $\begin{array}{c}0.158 \\
(0.298)\end{array}$ \\
\hline Illegal Immigration & $\begin{array}{l}0.216^{* *} \\
(0.061)\end{array}$ & $\begin{array}{c}0.200 \\
(0.175)\end{array}$ & $\begin{array}{c}0.140 \\
(0.116)\end{array}$ & $\begin{array}{c}0.128 \\
(0.106)\end{array}$ & $\begin{array}{c}0.555^{* *} \\
(0.170)\end{array}$ \\
\hline Racism Index & $\begin{array}{c}0.016 \\
(0.057)\end{array}$ & $\begin{array}{c}0.031 \\
(0.162)\end{array}$ & $\begin{array}{c}0.058 \\
(0.113)\end{array}$ & $\begin{array}{l}-0.131 \\
(0.099)\end{array}$ & $\begin{array}{c}0.178 \\
(0.147)\end{array}$ \\
\hline Male & $\begin{array}{c}0.228 * \\
(0.115)\end{array}$ & $\begin{array}{c}0.239 \\
(0.322)\end{array}$ & $\begin{array}{c}0.223 \\
(0.227)\end{array}$ & $\begin{array}{c}0.374 * \\
(0.190)\end{array}$ & $\begin{array}{c}0.073 \\
(0.309)\end{array}$ \\
\hline Anglo & $\begin{array}{c}0.262 \\
(0.193)\end{array}$ & $\begin{array}{l}-0.021 \\
(0.560)\end{array}$ & $\begin{array}{c}0.240 \\
(0.619)\end{array}$ & $\begin{array}{c}0.428 * \\
(0.288)\end{array}$ & $\begin{array}{c}0.162 \\
(0.473)\end{array}$ \\
\hline Income & $\begin{array}{l}-0.035^{* *} \\
(0.031)\end{array}$ & $\begin{array}{l}-0.306 * * \\
(0.099)\end{array}$ & $\begin{array}{c}0.028 \\
(0.066)\end{array}$ & $\begin{array}{l}-0.017 \\
(0.050)\end{array}$ & $\begin{array}{c}0.023 \\
(0.081)\end{array}$ \\
\hline Married & $\begin{array}{c}0.257^{*} \\
(0.122)\end{array}$ & $\begin{array}{c}0.784^{*} \\
(0.374)\end{array}$ & $\begin{array}{c}0.038 \\
(0.264)\end{array}$ & $\begin{array}{c}0.549 * * \\
(0.204)\end{array}$ & $\begin{array}{l}-0.160 \\
(0.327)\end{array}$ \\
\hline Education & $\begin{array}{c}0.038 \\
(0.047)\end{array}$ & $\begin{array}{c}0.153 \\
(0.116)\end{array}$ & $\begin{array}{l}-0.048 \\
(0.100)\end{array}$ & $\begin{array}{c}0.008 \\
(0.080)\end{array}$ & $\begin{array}{c}0.135 \\
(0.124)\end{array}$ \\
\hline Conservative & $\begin{array}{l}0.774^{* *} \\
(0.127)\end{array}$ & $\begin{array}{c}0.698 * \\
(0.356)\end{array}$ & $\begin{array}{l}0.712 * * \\
(0.258)\end{array}$ & $\begin{array}{l}0.686^{* *} \\
(0.221)\end{array}$ & $\begin{array}{l}1.313^{* *} \\
(0.318)\end{array}$ \\
\hline Republican & $\begin{array}{c}0.673^{* *} \\
(0.129)\end{array}$ & $\begin{array}{l}1.272^{* *} \\
(0.363)\end{array}$ & $\begin{array}{c}0.332 \\
(0.266)\end{array}$ & $\begin{array}{l}0.826^{* *} \\
(0.225)\end{array}$ & $\begin{array}{c}0.611 \\
(0.380)\end{array}$ \\
\hline Constant & $\begin{array}{l}-0.328 * * \\
(0.444)\end{array}$ & $\begin{array}{l}-3.130 * \\
(1.240)\end{array}$ & $\begin{array}{l}-2.543 * \\
(1.058)\end{array}$ & $\begin{array}{l}-3.122^{* *} \\
(0.677)\end{array}$ & $\begin{array}{l}-5.289 * * \\
(1.305)\end{array}$ \\
\hline Number of Cases & 763 & 138 & 195 & 270 & 160 \\
\hline Pseudo R-squared & 0.331 & 0.450 & 0.252 & 0.336 & 0.510 \\
\hline
\end{tabular}


the Tea Party movement. ${ }^{13}$ Overall, our findings support the contention that the Tea Party movement is, in some part, a reaction to the Republican Party's movement toward the neo-conservative, moral-majority wing over the past three decades.

While the findings regarding the role of traditional values are perhaps not surprising, the wholly insignificant coefficients associated with racial resentment provide some new insight. Despite what some argue, racism seems to play no role in driving up support for the Tea Party movement. In no region of the nation is Tea Party movement support associated with higher levels of racial resentment. In fact, notwithstanding statistical significance, a negative relationship between racial resentment and support for the movement emerges in the precise region where we would expect a strong positive relationship-the South. ${ }^{14}$ It thus appears that the common and persistent charges that the Tea Party movement is, at base, a racist one may be misplaced.

Our data offer two points of evidence for reconciling this statistical non-finding regarding racial attitudes with the common perception of a racist movement. First, the Tea Party movement may be painted as a racist one because Tea Party supporters are more likely to be white Southerners. While less than one in five (19.4\%) minority non-Southerners and about 36 percent of Anglo non-Southerners report supporting the movement, almost half of white Southerners (47.1\%) express support. ${ }^{15}$ This fact might lead many to falsely conclude that racial hatred is driving the movement. Second, our evidence bolsters that of some previous studies (see Campo-Flores 2010) illustrating that supporters of the Tea Party movement express more racist attitudes than non-supporters. As Table 3 illustrates, movement supporters express higher levels of racist sentiment on the overall racial attitudes index and on each of the four items in our racial attitudes index. ${ }^{16}$ Tea Party movement supporters are more likely to believe that African-Americans have worse jobs, income, and housing than white people because African-Americans are not as motivated to pull themselves out of poverty and have less inborn ability to learn. Similarly, movement supporters are less likely to believe that these differences are due to discrimination or poorer educational opportunities. Our findings thus suggest that supporters of the Tea Party movement do indeed look more like stereotypical racists (i.e., white Southerners) and do, in fact, express more racist attitudes on a range of measures. At the same time, our results illustrate that, in comparison to other factors, racist attitudes are not what draw people to the movement. Tea Party supporters may indeed be more racist than non-supporters, but this racism is not what causes them to be movement supporters.

Our results further reveal interesting and expected regional patterns when it comes to concerns about illegal immigration and the economy, as 
Table 3. Comparison of Tea Party Supporters and Non-Supporters

\begin{tabular}{ccc}
\hline Non-Tea Party & Tea Party \\
Supporter & Supporter \\
$(\mathrm{N}=612)$ & $(\mathrm{N}=352)$ \\
\hline
\end{tabular}

Racism: Additive index of four items (ranges 0-4; means reported)

$$
1.5
$$

"On average, African Americans have worse jobs, income, and housing than white people.

Do you think these differences are-"

"because most African-Americans just don't have the motivation or will power to pull themselves up out of poverty."
(1) Yes
34.3
(0) No
65.7
47.3
52.7
"mainly due to discrimination."
(1) No
60.8
84.0
(0) Yes
39.2
16.0

"because most African Americans have less in-born ability to learn."
(1) Yes
8.0
9.8
(0) No
92.0
90.2

"because most African Americans don't have the chance for the education that it takes to rise out of poverty."
(1) No
46.1
71.0
(0) Yes
53.9
29.0

Cell entries are valid percentages (missing cases are excluded).

well as anti-government sentiment. While anti-immigrant attitudes prove to be most important in the West, economic concerns and, especially, antigovernment sentiments appear to be the strongest predictors of Tea Party movement support in the non-Western regions of the nation. ${ }^{17}$ In the East, economic concerns seem to be the key predictive factor, while anti-government sentiment plays the largest role in the Midwest. Finally, in the South, both factors are important.

\section{In the West It's About Illegal Immigration, Maybe}

In the Western region, and only this region, anti-immigrant attitudes appear to increase support. In fact, views on illegal immigration appear to be the sole factor (besides being Conservative) increasing movement support in this part of the nation, and exhibit a substantial impact on the likelihood that a person will support the movement. To compare the substantive effects of 
the various statistically significant factors, we calculate predicted probabilities and present them in Figure 1. For comparison, the impact that Conservatism has on Tea Party support is displayed in Figure 1 as well (indicated with the white bar on the right side of each regional cluster). As this figure illustrates, a typical Westerner who perceives illegal immigration to be an "extremely serious threat" to the nation is much more likely to support the Tea Party movement than one who does not view illegal immigration as a threat. ${ }^{18}$ The former has about a 12 percent chance of being a Tea Party supporter, while the latter exhibits only about a 0 . percent chance. This impact dwarfs that exhibited by Conservatism, which only increases movement support by about 3.3 percent.

While impressive, the magnitude of the immigration effect must not be overstated. The influence of this variable is likely influenced by the context within which the interviews were conducted. Respondents were interviewed in the midst of massive media coverage of Arizona's restrictive illegal immigrant law (SB1070), which was signed on April 23, 2010, and went into effect on July 29, 2010. Respondents, especially those in the West, were likely to have issues of illegal immigration in the forefront of their minds. Thus, it is not surprising that such a strong statistical relationship emerges here.

\section{Figure 1. Impact of Different Factors on Support for Tea Party}

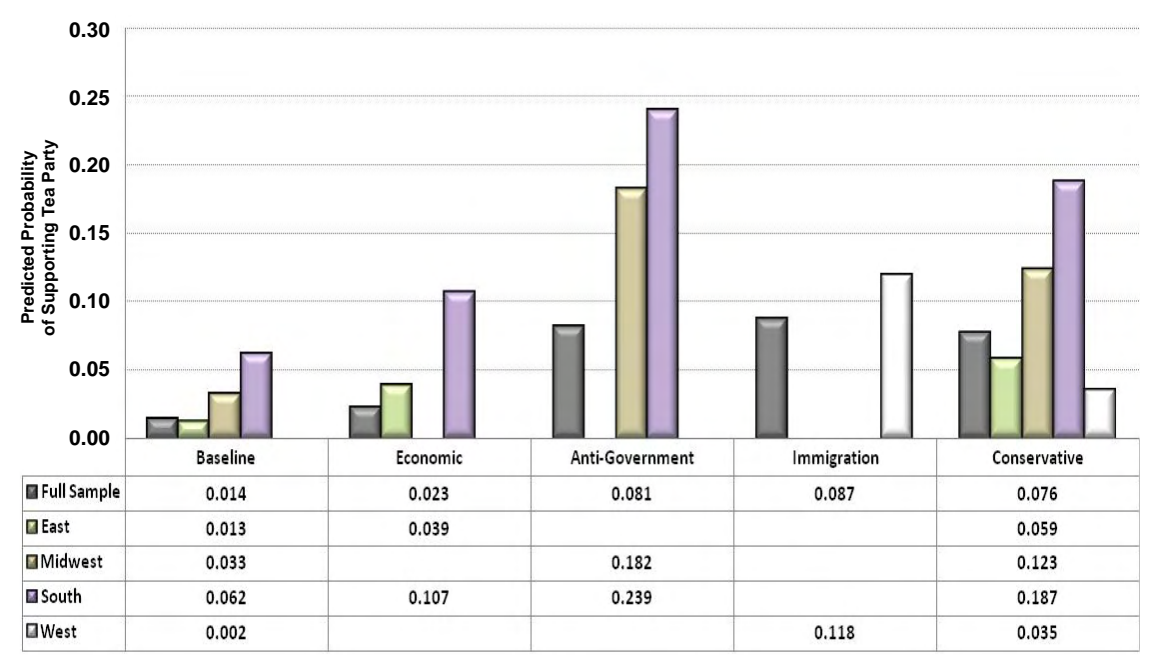

Probabilities estimated using regression results presented in Table 2. For the baseline probability, all issue variables were set to their minimum values and all control values set to their median values. Probabilities for each issue area were calculated using the maximum value for the issue and median values for all control variables. 
Given these possible contaminating effects in the West, we explored the possibility that the link between immigration attitudes and movement support were serving as a proxy for economic concerns. Perhaps Westerners were expressing fears over illegal immigration in reaction to the perception that valuable jobs were being filled by illegal immigrants in a tough economic climate. To investigate this possibility, we correlated the illegal immigration concerns item with a measure of respondents' perceptions about how serious a threat unemployment is to the future well-being of the United States (measured on a five-point scale where $1=$ not a threat and $5=$ =xtremely serious threat). While these two items are positively and significantly related in all regions, the magnitude of the effect is strongest in the West. ${ }^{19}$ These findings suggest that while immigration attitudes are an important predictor of Tea Party movement support in the West, economic issues related to minority relations might be playing a role as well. ${ }^{20}$ These statistical results are borne out by the results of recent elections in the West where conservative candidates, even established Republicans found themselves having to conform to Tea Party belief's concerning immigration. John McCain found himself fighting for primary survival against Tea Party supported candidate J.D. Hayworth, and was forced to play to the Tea Party supporters in the state supporting more stringent immigration reforms such as Governor Jan Brewer's immigration law (Allen 2010; Hunt 2010). A similar story played out in New Mexico, where Tea Party favorite Susana Martinez, a former prosecutor, made immigration the center of her gubernatorial campaign, touting her record on her website and in campaign ads for going after illegal immigrant law-breakers (Gomez 2010; Lacey 2010; Massey 2010).

Interestingly, much of the immigration rhetoric in this region was tied to the availability of jobs. In both Utah and California, candidates tied their immigration appeals to hiring of illegal immigrants. Three-term Senator Robert Bennett of Utah faced, and ultimately lost, a tough fight in the primaries against Tea Party favorite Mike Lee (Burr 2010; Canham 2010; Lee 2010), with Lee espousing a hard-line immigration policy that would punish businesses hiring undocumented workers. Even in the strongly blue state of California, Republican candidates found themselves having to take right of center stances on immigration. The political climate led candidates like Meg Whitman to call for the U.S. "build an 'economic fence' with a strong everification system that holds employers accountable for only hiring documented workers" (Whitman 2010).

\section{In the East "It's the economy, stupid"}

For Easterners, believing the economy is the most important problem facing the nation increases support for the Tea Party movement (see Table 1). 
The typical Easterner who mentions the economy as the most important problem three times has about almost a 4 percent chance of supporting the movement. In contrast, a typical Easterner who does not mention the economy is the most important problem at all exhibits only about a 1.3 percent chance of supporting the movement. Though this impact is not especially strong, it is close to the impact that Conservatism exhibits. Further, in the East it appears that those who are married and call themselves Republicans are also more likely to be Tea Party movement supporters. Interestingly, the wealthier in this region are less supportive of the movement, suggesting that the movement may not be drawing those who believe that taxes on the wealthy are too high, a finding that fits well with previous research. Since eastern states trend Democratic, income's muted role in predicting support for the movement fits well with arguments that income is likely to matter more in predicting partisan support in "red America than in blue America" (Gelman et al. 2008, 49-51).

Again, anecdotal evidence from the midterm elections bears out these statistical findings. In the East, particularly the battleground state of Pennsylvania, Senatorial candidate Pat Toomey and gubernatorial candidate John Corbett, both seeking to appeal to Tea Party supporters, kept to the issue that mattered most to Pennsylvania voters - the economy (Barnes 2010; Wereschagin 2010). In a heated debate with Democratic opponent Joe Sestak, Toomey asked, "Where are the jobs? The idea that just borrowing and spending federal money is going to generate prosperity is just a fallacy." Toomey also touted his business experience as an investment banker and his doctorate in political economy from Harvard adding, "Joe has no experience in business and doesn't understand the consequences of the really bad policies he's proposing. I understand business" (Wereschagin 2010). Corbett, though not a favorite of the Tea Party, was forced by a Tea Party challenger in the gubernatorial primary to move his position right of center on economic issues. He signed a pledge to not raise taxes and as Attorney General of Pennsylvania, added his state to the list of states challenging the Obamasupported healthcare law. In his defense of the lawsuit, Corbett, appealing to Pennsylvania voter's economic rationale, claimed the federal government was interfering with intrastate commerce.

\section{A Rejection of Government in the Midwest}

In the Midwest, anti-government sentiment represents the sole factor (besides Conservatism) increasing support for the movement (see Table 1), and the impact of this sentiment is strong (see Figure 1). While the typical Midwesterner who does not believe the government is part of the problem has about a 3.3 percent chance of being a Tea Party supporter, one who sees 
the government as "more a part of the problem" than the solution has about an 18.2 percent chance of being a supporter. This effect is among the strongest effects we observe, and it trumps the impact of Conservatism in this region as well.

The campaign rhetoric in this region readily corroborates our findings. In Wisconsin, a state hit hard by recession and the loss of manufacturing and construction jobs, voters ousted three-term Senator Russ Feingold in favor of Tea Party supported businessman Ron Johnson (Bivins, 2011; Oliphant 2010; Schaper 2010). Johnson, who said of the Tea Party, "their issues are my issues," criticized Feingold's votes on federal government programs such the Obama-supported healthcare law and the economic stimulus bill (Bivins 2011; Oliphant 2010). Feingold's eighteen years of government experience seemed to be a turn-off for voters who looked more favorably upon Johnson's private sector experience in the plastics manufacturing business. Feingold even acknowledged this stating, "People are hurting, and they have a right to look at what you've done. They have a right to say, 'OK, this guy's been in office-is he part of the solution or part of the problem.'” (Schaper 2010). In one of their debates, Johnson harped upon this very issue claiming of Feingold, "He's been in politics all his life. He's never created a job. I have.” (Oliphant 2010). Likewise, Ohio had lost an estimated 400,000 jobs under Democrat Ted Strickland's governorship. This opportunity was ripe for former Republican Congressman and Tea Party favorite John Kasich to make the anti-government argument (Memoli 2010; Zeleny 2010a, 2010b). Kasich, a key conservative Representative in the 1990s who helped to balance the federal budget, argued that what Ohio needed was less government intrusion. Strickland, however, aligned himself with national politicians, further fueling Kasich's rhetoric, making it an "us" versus "them" argument that ultimately prevailed.

\section{Southerners Are Just Plain Upset}

Finally, in the South, both economic concerns and anti-government sentiment increase support for the movement (see Table 1), and anti-government sentiment exhibits about twice as strong an impact as economic concerns (see Figure 1). While economic concerns increase the likelihood of movement support by about 4.3 percent, anti-government sentiment boosts the chances of support by almost 18 percent. While a typical Southerner who views the government as more a part of the problem than the solution has almost a one in four (23.9\%) chance of supporting the movement, a similar person who does not see the government as the problem has only about a 6 percent chance of supporting the movement. Economic concerns move the likelihood of supporting from about 6 percent to only about 11 percent. In 


\section{2 | Stacy G. Ulbig and Sarah Macha}

fact, the role that anti-government sentiment in the South plays in Tea Party movement support is the strongest in our analysis.

The importance of anti-government sentiment in this region was readily on display in recent elections. The first official Tea Party movement victory of the mid-term election occurred when Rand Paul, a longtime favorite of the movement, won a Kentucky Senate seat. Paul stuck to a message that was anti-government (Gerth 2010; Phillips 2010), saying [t]he people are sick and tired of an overreaching government, of a deficit out of controlthey want their government back” (Gerth 2010). Texas' gubernatorial election offered equally as strong anti-government appeals. Governor Rick Perry easily won reelection in Texas and did so with a hard-line Tea Party wave of anti-federal government rhetoric that led to the insinuation of state secession. In front of an enthusiastic Tea Party rally in Austin, Perry said, "We've got a great union. There's absolutely no reason to dissolve it. But if Washington continues to thumb their nose at the American people, you know, who knows what might come out of that" (FOX News 2009). Later Perry had to clarify his remarks citing the overall frustration Texans have with the federal government, "They're sick of Washington overspending. They're sick of Washington mandating to states how to run their businesses" (Barabak 2009). Perry shaped the campaign against the current federal government, so much so that Democratic opponent Bill White refused to be seen with Obama when the President visited Texas (Satija 2010).

\section{Summary and Conclusions}

Overall, our expectations about the impact that varied sources of Tea Party movement support were generally borne out. We found that traditional, moral values play no role in increasing support for the movement, further substantiating claims that the movement formed in reaction to the Republican Party's shift toward the neo-conservative wing over the past three decades. Counter to much popular sentiment, we find that racial resentment plays no role in predicting movement support, either. Though Tea Party supporters are more likely to be white Southerners and to express more racist attitudes, these attitudes do not appear to cause a person to support the movement. We do find that economic concerns, anti-government sentiment, and views about illegal immigration play important, but varied roles in movement support across the nation. Viewing illegal immigration as a threat to the nation increases support for the Tea Party movement, but only in the West (and these attitudes may be masking deeper concerns about the economy). Economic concerns are the key factor increasing movement support in the East, while anti-government sentiment boosts support in the Midwest 
and both play key roles in the South where anti-government sentiment drive support more than economic concerns.

Our statistical findings comport well with the campaign rhetoric displayed across the nation in recent mid-term Congressional and gubernatorial races. In the West, even veteran Republican candidates found themselves appealing to Tea Party supporters on the economic impact of illegal immigration, while in the East Tea Party supported candidates kept the focus mainly on the economy. Meanwhile, campaigns across the Midwest called on anti-government themes to rally support from key Tea Party constituents, and some Southern candidates railed so adamantly against the federal government that they harkened the possibility of state secession.

Overall, our results help to explain the common perception of the Tea Party movement as a discombobulated grassroots movement with no coherent policy platform. While there are few issues that unify movement supporters nationwide, distinct regional policy priorities exist. Our finding that the movement appeals to voters in different regions in different ways, helps to explain why "all kinds of people sought to hitch their wagons" to the movement (Mead 2011). Because voters in different parts of the nation are drawn to the movement for different reasons, it makes sense that voters as diverse as "[a]ffluent suburban libertarians, rural fundamentalists, ambitious pundits, unreconstructed racists, and fiscally conservative housewives all can and do claim to be Tea Party supporters” (Mead 2011). 


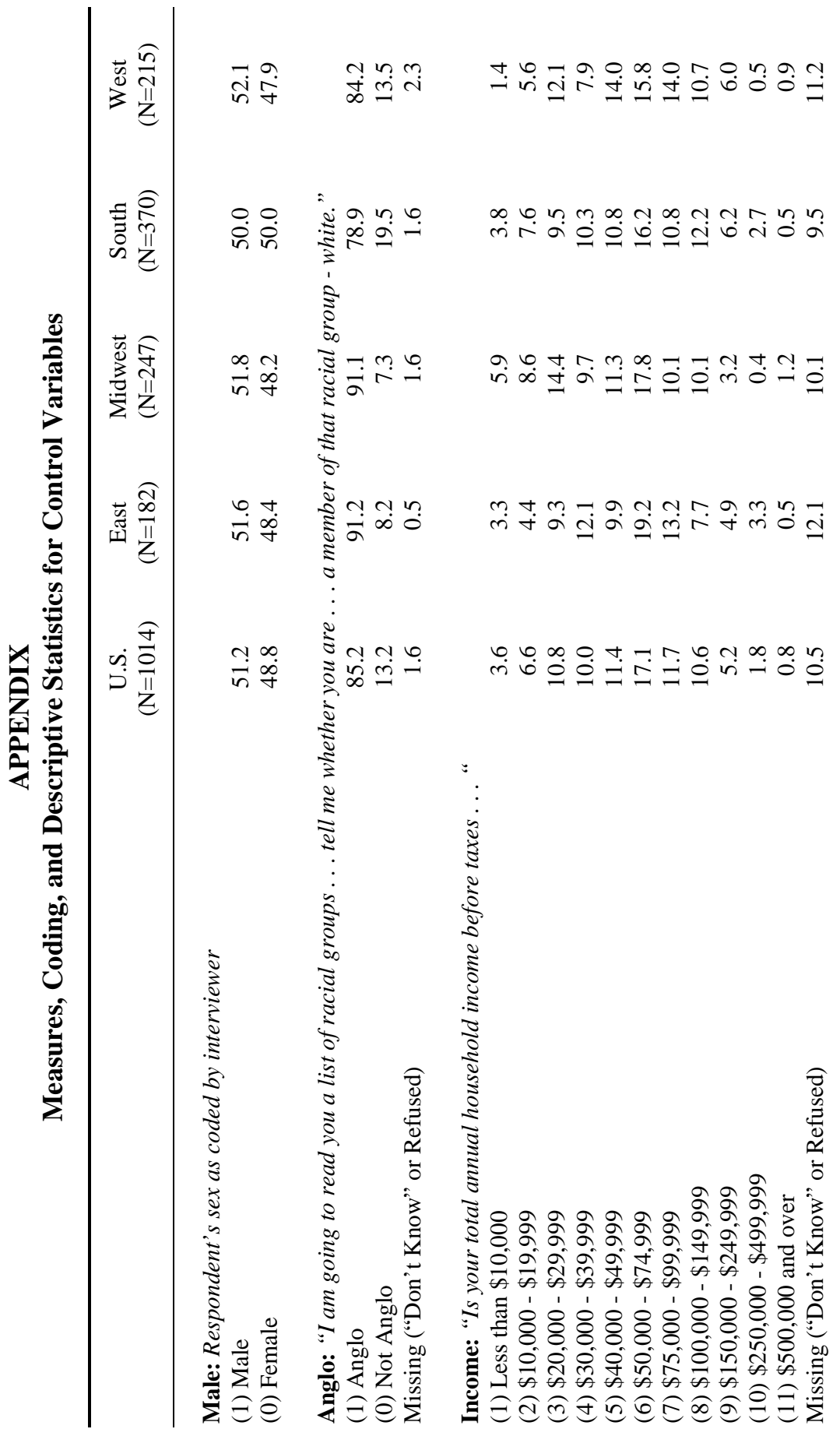




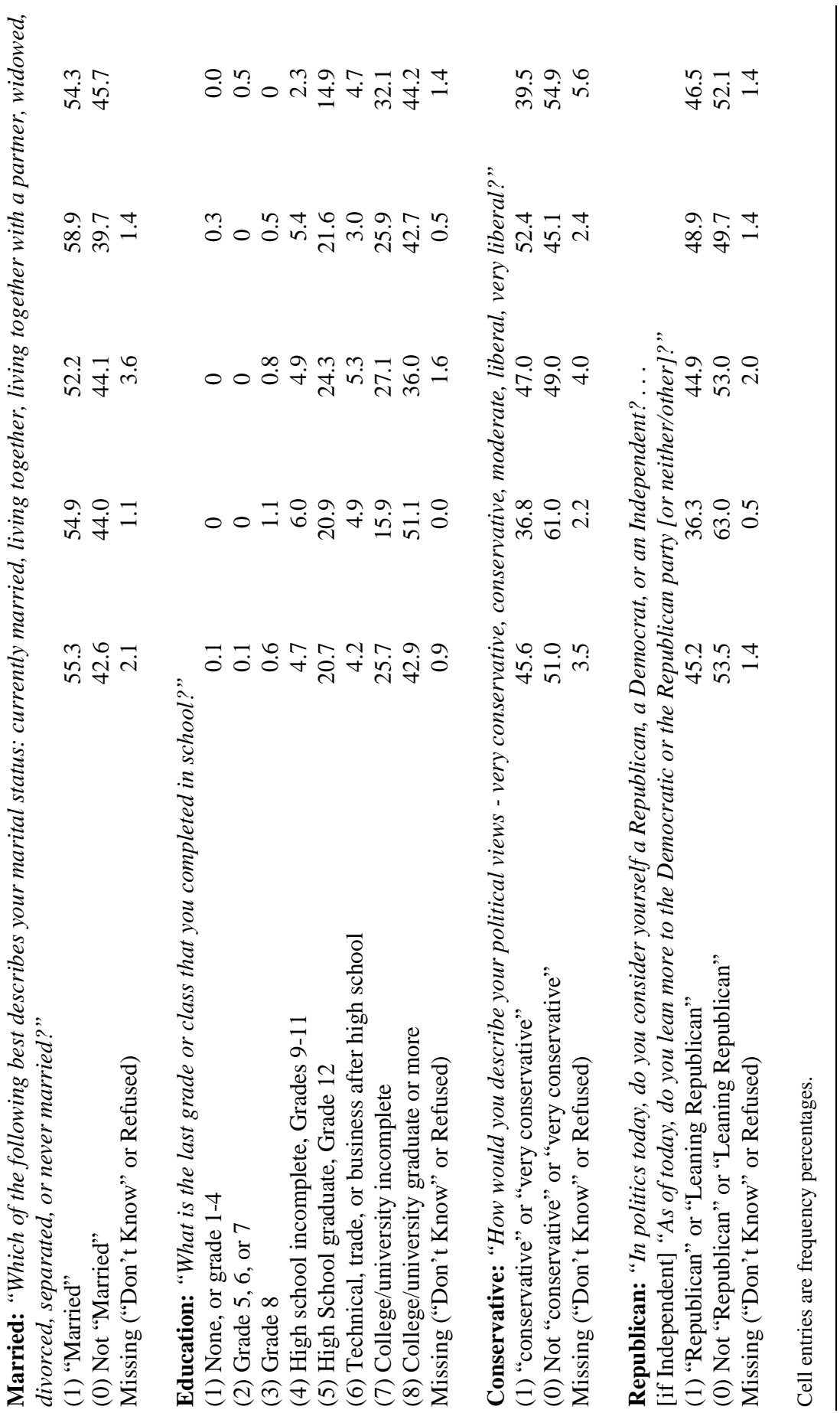




\section{6 | Stacy G. Ulbig and Sarah Macha}

\section{NOTES}

${ }^{1}$ Since the Tea Party movement lacks many of the characteristics traditionally expected of a political party, we do not mean to imply that supporters of the movement actually identify themselves as Tea Party members instead of members of another political party. Instead, we take an expression of support of the movement's ideas more generally.

${ }^{2}$ The data (USAIPOUSA2010-08) are available for download from the Roper Center for Public Opinion Research data archive. While would have preferred to use data collected at a time more proximate to the midterm election, available data from that timeframe does not contain all the predictive variables necessary for this analysis. A search of the National Election Studies, ICPSR, and Roper data archives reveals a number of datasets covering the midterm election time period, but these data lack measures of all the concepts relevant to this study, especially racial attitudes.

${ }^{3}$ The East region includes: ME, NH, VT, MA, RI, CT, NY, NJ, PA, MD, DE, WV, DC; the Midwest Region includes: OH, MI, IN, IL, WI, MN, IA, MO, ND, SD, NE, KS; the Southern region includes: VA, NC, SC, GA, FL, KY, TN, AL, MS, AR, LA, OK, TX; the West region includes: MT, AZ, CO, ID, WY, UT, NV, NM, CA, OR, WA, HI, AK.

${ }^{4} \mathrm{We}$ also tested two different coding strategies for this dependent variable in all of the regression models explained below. First, we tested a measure that excluded those respondents offering "neither" a supporter nor an opponent. Second, we tested a threepoint measure ( 1 =opponents; $2=$ neither; $3=$ supporter) with both ordered probit and multinomial probit models. The statistical and substantive results are unchanged by these substitutions.

${ }^{5}$ Respondents were also allowed to volunteer that the federal government is both a part of the problem and solution. Such responses were included in our analysis and coded 0.

${ }^{6} \mathrm{We}$ also initially tested additive and weighted versions of a three-item antigovernment sentiment index. The index included the anti-government sentiment item presented here, as well as items asking respondents how much of a threat the size and power of the federal government was to the future well-being of the nation and whether the federal government was doing too much in the economy. The substitution of either version of the index for the single anti-government sentiment item performs statistically and substantively the same as the single item, but does reduce the number of cases available for analysis due to missing values on the two additional items included in the index. Consequently, we rely on the single measure of anti-government sentiment in the models presented below.

${ }^{7}$ We also initially included a measure of debt/deficit attitudes, which asked respondents to rate how "serious a threat" federal government debt was "to the future well-being of the United States" on a five point response scale (1=not a threat to $5=$ =xtremely serious threat). This measure is highly correlated with our anti-government measure, and when included in the models presented below, proves to be statistically insignificant in the full sample and each of the four regional subsamples. Since the addition of this variable adds no explanatory power to any of our models but does increase multicollinearity in the models, we exclude it from the analyses presented here.

${ }^{8}$ We also initially tested additive and weighted versions of a three-item traditional values index. The index included the traditional values item presented here, as well as items asking respondents how important the issue of abortion/gay marriage is to them and whether respondents volunteered the most important problem facing the national to be "ethical-moral-religious decline." The substitution of either version of the index for the 
single traditional values item performs statistically and substantively the same as the single item, but does reduce the number of cases available for analysis due to missing values on the two additional items included in the index. Consequently, we rely on the single measure of traditional values in the models presented below.

${ }^{9}$ This similarity in concern over illegal immigration might be due to the timing of the interviews. Respondents were interviewed in the midst of massive media coverage of Arizona's restrictive illegal immigrant law (SB1070), which was signed on April 23, 2010, and went into effect on July 29, 2010.

${ }^{10}$ We constructed an alternative version of this index using principal components factor analysis and weighting each item the percent of variance explained. The weighted index correlates with the original index at 0.954 (sig: 0.000), and, the substitution of the weighted index for the original index in the models presented below produces the same statistical and substantive results. Consequently, we include our original, simpler index in the models presented here.

${ }^{11}$ See Appendix for details on question wording, variable coding, and descriptive statistics of all control variables.

${ }^{12}$ Concerned that the income measure was suppressing our number of valid cases, we also ran all the models excluding the income measure. While the number of cases in each model slightly increases, the statistical and substantive results are unchanged by this exclusion.

${ }^{13}$ To test the possibility that the inclusion of the ideology and partisanship control variables may be serving to mask the impact of traditional values, we ran alternative specifications of all our models excluding these controls. Though the traditional values item is collinear with both partisanship and ideology, the traditional values item remains statistically insignificant when these two control variables are excluded from the analysis.

${ }^{14}$ Restricting this measure to the two more overt measures of racial sentiment (items 'a' and 'c') offers the same statistical and substantive results.

${ }^{15}$ Only $14.8 \%$ of Southern non-Anglo respondents express movement support.

${ }^{16}$ The difference in mean racial attitude index scores for Tea Party supporters and non-supporters is statistically significant at $\mathrm{p}<0.01$ (two tailed).

${ }^{17}$ Anti-government sentiment represents the single most powerful influence on movement support, a fact supported by our data when it comes to Presidential and Congressional approval. When we add presidential disapproval as a predictor in our model, it is the single most important predictor of Tea Party support (and many times the only significant predictor).

${ }^{18}$ Predicted probability of supporting the Tea Party movement was estimated using the regression results presented in Table 2 . For the baseline probability, all issue variables were set to their minimum values and all control values set to their median values. Probabilities for each issue area were calculated using the maximum value for the issue and the median values for all control variables. So, in this example, the "typical" Westerner was a non-conservative, non-Republican, married, Anglo, male, with a technical degree, earning \$50-\$75K per year who did not mention the economy as the most important problem facing the nation, did not see government as more of the problem than the solution, did not believe the government should promote traditional values, and had the lowest racism index score.

${ }^{19}$ Correlations by region: West $=0.3403$; Midwest $=0.3356$; East $=0.2391$; South $=$ 0.1974 (all significant at $\mathrm{p}<0.01$ ).

${ }^{20}$ As a secondary test of the possibility that concerns about illegal immigration might be serving as a proxy for economic concerns, we substituted a measure of feelings about minority job discrimination for the racism index in our regression models. This job 


\section{8 | Stacy G. Ulbig and Sarah Macha}

discrimination measure was comprised of two variables: (a) the second item in our racism index (reference discrimination) and (b) a question asking respondents if they felt "minorities in this country have equal job opportunities as whites, or not." We find this "job discrimination" index is positively and significantly related to support for the Tea Party movement in the West, but in no other region. At the same time, the immigration measure remains statistically significant as well.

\section{REFERENCES}

Allan, Nicole. 2010. August 23, 2010. Immigration Politics a Boon for Jan Brewer and John McCain. The Atlantic, August 23. http://www.theatlantic.com/politics/archive/ 2010/08/immigration-politics-a-boon-for-jan-brewer-and-john-mccain/61904/ (March 24, 2011).

Baker, Peter. 2010. Strange Brew. Foreign Policy 181:38-40.

Barnes, Tom. 2010. Hoeffel criticizes Corbett on healthcare. Pittsburgh Post-Gazette, March 30. http://www.post-gazette.com/pg/10089/1046582-178.stm (March 24, 2011).

Barabak, Mark Z. 2009. Texas Gov. Rick Perry’s Words Resonate Near and Far. Los Angeles Times, May 18. http://articles.latimes.com/2009/may/18/nation/na-perry18 (September 29, 2011).

Beck, Paul Allen. 1979. The Electoral Cycle and Patterns of American Politics. British Journal of Political Science 9(1):129-156.

Berlet, Chip. 2011. Taking Tea Parties Seriously: Corporate Globalization, Populism, and Resentment. Perspectives on Global Development \& Technology 10(1):11-29.

Bivins, Larry. 2011. Wisconsin Sen. Ron Johnson to Conservatives: We Need More Allies. Green Bay Press Gazette, February 20. http://www.greenbaypressgazette .com/article/20110210/GPG0101/110210124/Wisconsin-Sen-Ron-Johnson-conservatives-We-need-more-allies- (March 24, 2011).

Bullock III, Charles S., Donna R. Hoffman, and Ronald Keith Gaddie. 2006. Regional Variations in the Realignment of American Politics. Social Science Quarterly 87(3):494-518.

Burnham, Walter Dean. 1970. Critical Elections and the Mainsprings of American Politics. New York: Norton.

Burr, Thomas. 2010. Lee: Immigrant Birth Study Shows Need for Federal Action. Salt Lake Tribune, October 19. http://www.sltrib.com/sltrib/home/50101676-76/lee-citizenship-born-birthright.html.csp (March 24, 2011).

Calfano, Brian Robert, and Paul A. Djupe. 2009. God Talk: Religious Cues and Electoral Support God Talk: Religious Cues and Electoral Support. Political Research Quarterly 62(2):329-339.

Campbell, David E., and Robert D. Putnam. 2011. Crashing the Tea Party. New York Times, August 17, 2011. http://www.nytimes.com/2011/08/17/opinion/crashingthe-tea-party.html.

Campo-Flores, Arian. 2010. Are Tea Partiers Racist? Newsweek, April 26. http://www. newsweek.com/ 2010/04/25/are-tea-partiers-racist.html (March 24, 2011).

Canham, Matt. 2010. Granato, Lee Clash Over Fate of Illegal Immigrants. Salt Lake Tribune, September 21. http://www.sltrib.com/sltrib/home/49967366-76/granatoimmigrants-lee-illegal.html.csp (March 24, 2011).

Courser, Zachary. 2010. The Tea Party at the Election. Forum 8(4):1-18. 
Cunningham, Benjamin. 2010. More Manic than Movement. New Presence: The Prague Journal of Central European Affairs 14(2):21-25.

Downs, Anthony. 1957. An Economic Theory of Democracy. New York: Harper and Row Publishers.

Elazar. 1966. American Federalism: A View from the States. New York: Crowell.

Erikson, Wright, and McIver. 1993. Statehouse Democracy: Public Opinion and Policy in the American States. Cambridge: Cambridge University Press.

FOXNews.com. 2009. Governor Says Texans May Want to Secede From Union but Probably Won't FOX News, April 15. http://www.foxnews.com/politics/2009/04/ 15/governor-says-texans-want-secede-union-probably-wont/ (March 24, 2011).

Fraser, Steve, and Joshua B. Freeman. 2010. In the Rearview Mirror, History's Mad Hatters: The Strange Career of Tea Party Populism. New Labor Forum. 19(3):75-81.

Gelman, Andrew, David Park, Boris Shor, Joseph Bafumi, and Jeronimo Cortina. 2008. Red State, Blue State, Rich State, Poor State: Why Americans Vote the Way They Do. Princeton, NJ: Princeton University Press.

Gerstle, Gary. 2010. The GOP in the Age of Obama: Will the Tea Party and Republican Establishment Unite or Fight? New Labor Forum 19(3):23-31.

Gerth, Joseph. 2010. Rand Paul Addresses Tea Party Festival in Frankfort. Courier-Journal, July 10. http://www.courier-journal.com/apps/pbcs.dll/article?AID=20107100349 (March 24, 2011).

Gold, Howard J. 1995. Third Party Voting in Presidential Elections: A Study of Perot, Anderson, and Wallace. Political Research Quarterly 48(4):775-794.

Gomez, Alan. 2010. New Mexico’s Governor-Elect Unlikely to Follow Arizona's Lead. USA Today, November 9. http://www.usatoday.com/news/nation/2010-11-09newmexico09_ST_N.htm (March 24, 2011).

Graham, Michael. 2009. That's No Angry Mob, That's My Mom: Team Obama's Assault on Tea-Party, Talk-Radio Americans. Washington, DC: Regnery Publishing, Inc.

Green, John C., and James L. Guth. 1988. The Christian Right in the Republican Party: The Case of Pat Robertson's Supporters. Journal of Politics 50(1):150-165.

Harris, Lee. 2010. The Tea Party vs. the Intellectuals. Policy Review 161:3-14.

Hertzke, Allen D. 1993. Echoes of Discontent: Jesse Jackson, Pat Robertson, and the Resurgence of Populism. Washington, DC: Congressional Quarterly Press.

Hirano, Shigeo, and James M. Snyder, Jr. 2007. The Decline of Third-Party Voting in the United States. Journal of Politics 69(1):1-16.

Hunt, Albert. 2010. Tea Party Doesn't Need Votes to Win U.S. Elections. New York Times, September 26. http://www.nytimes.com/2010/09/27/us/27iht-letter.html?_r=1 (March 24, 2011).

Kaufmann, Karen M. 2002. Culture Wars, Secular Realignment, and the Gender Gap in Party Identification. Political Behavior 24(3):283-307.

Killian, Mitchell, and Clyde Wilcox. 2008. Do Abortion Attitudes Lead to Party Switching? Do Abortion Attitudes Lead to Party Switching? Political Research Quarterly 61(4):561-573.

Koch, Jeffrey. 1998. The Perot Candidacy and Attitudes toward Government and Politics Political Research Quarterly 51(1):141-153.

Lacey, Mark. 2010. Latino Vote Turnout Likely to Lag, Poll Says. New York Times, October 5. http://www.nytimes.com/2010/10/06/us/politics/06immig.html (March 24, 2011).

Lee, Davidson. 2010. Granato, Lee Battle Over Who is Extremist. Salt Lake Tribune, October 29. http://www.sltrib.com/sltrib/home/50561179-76/lee-granato-utah-term. html.csp (March 24, 2011). 
Lieske, Joel. 1993. Regional Subcultures of the United States. Journal of Politics 55(4): 888-913.

Massey, Barry. 2010. Richardson's shadow looms in hard-fought NM race. Washington Post, October 5. http://www.washingtonpost.com/wp-dyn/content/article/2010/10/ 05/AR2010100500455.html (March 24, 2011).

Mazmanian, Daniel A. 1974. Third Parties in Presidential Elections. Washington, DC: The Brookings Institution.

McCann, James A., Ronald B. Rapoport, and Walter J. Stone. 1999. Heeding the Call: An Assessment of Mobilization into H. Ross Perot's 1992 Presidential Campaign. American Journal of Political Science 43(1):1-28.

McGrath, Ben. 2010. The Movement-The Rise of Tea Party Activism. New Yorker, February 1. http://www.newyorker.com/reporting/2010/02/01/100201fa fact mcgrath?currentPage=2 (February 23, 2011).

Mead, Walter Russell. 2011. The Tea Party and American Foreign Policy. Foreign Affairs 90(2):28-44.

Memoli, Michael. 2010. Republican John Kasich poised to be Ohio governor. Los Angeles Times, November 2. http://articles.latimes.com/2010/nov/02/news/la-pn-ohio-races20101103 (March 24, 2011).

Miller, Arthur H., and Thomas F. Klobucar. 2003. The Role of Issues in the 2000 U.S. Presidential Election. Presidential Studies Quarterly 33(1):101-124.

Oldfield, Duane M. 1995. The Christian Right and the Presidential Nominating Process. In In Pursuit of the White House: How We Choose Our Presidential Nominees, ed. William G. Mayer. Chatham, NJ: Chatham House.

Oliphant, James. 2010. Sen. Russ Feingold Battles 'Tea Party' Challenger in Wisconsin. Los Angeles Times, October 12. http://articles.latimes.com/2010/oct/10/nation/lana-feingold-race-20101010 (March 24, 2011).

O’Rourke, P.J. 2010. Innocence Abroad. World Affairs 173(3):5-14.

Parker, Christopher. 2010. Multi-State Survey on Race and Politics. http://depts.washington.edu/uwiser/racepolitics.html (March 24, 2011).

Pastor, Gregory S., Walter J. Stone, and Ronald B. Rapoport. 1999. Candidate-Centered Sources of Party Change: The Case of Pat Robertson, 1988. Journal of Politics 61(2):423-444.

Phillips, Kate. 2010. After Explaining a Provocative Remark, Paul Makes Another. New York Times, May 21. http://www.nytimes.com/2010/05/22/us/politics/22paul.html (March 24, 2011).

Rasmussen, Scott, and Doug Schoen. 2010. Mad as Hell, How the Tea Party Movement is Fundamentally Remaking Our Two-Party System. New York: Harper Collins.

Rosenstone, Steven J., Roy L. Behr, and Edward H. Lazarus. 1996. Third Parties in America: Citizen Response to Major Party Failure, 2nd ed. Princeton, NJ: Princeton University Press.

Ross, Benjamin. 2006. Democrats and Middle America. Dissent 53(1):8-11.

Satija, Neena. 2010. Bill White Passes on Appearing with President Barack Obama and Doesn't Want to Talk About It. Dallas Morning News, August 6. http://www. dallasnews.com/news/community-news/dallas/headlines/20100806-Bill-Whitepasses-on-appearing-with-4752.ece (March 24, 2011).

Schaper, David. 2010. Democrat Feingold Faces Tough Battle in Wisconsin. National Public Radio, September 28. http://www.npr.org/templates/story/story.php?storyId $=130175533$ (March 24, 2011).

Schlesinger, Joseph A. 1994. Political Parties and the Winning of Office. Ann Arbor: University of Michigan Press. 
Stone, Walter J., and Ronald B. Rapoport. 2001. It's Perot Stupid! The Legacy of the 1992 Perot Movement in the Major Party System, 1994-2000. PS: Political Science and Politics 34(1):49-58.

Stone, Walter J., and Ronald B. Rapoport. 2005. Three's a Crowd: The Dynamic of Third Parties, Ross Perot, and Republican Resurgence. Ann Arbor: University of Michigan Press.

Sundquist, James L. 1983. Dynamics of the Party System, rev. ed. Washington, DC: The Brookings Institution.

Tilden, William W. 2011. The Psychohistorical Roots of the American 'Tea Party' Movement. Journal of Psychohistory 28(3):214-222.

Wereschagin, Mike. 2010. U.S. Senate Debate Fierce as Candidates Hurl Extremist Barbs. Pittsburgh Tribune-Review, October 23. http://www.pittsburghlive.com/x/leadertimes/news/s 705761.html (March 24, 2011).

Whitman, Meg. 2010. Meg Whitman: Immigration Reform, with Respect. Los Angeles Times, March 27. http://articles.latimes.com/2010/mar/27/opinion/la-oe-whitman 27-2010mar27 (March 24, 2011).

Winneg, Kenneth, and Kathleen Hall Jamieson. 2005. 'Elections': Party Identification in the 2004 Election. Presidential Studies Quarterly 35(3):576-589.

Zeleny, Jeff. 2010a. In Ohio, Gauge for Midterms, Economy Rules. New York Times, May 29. http://www.nytimes.com/2010/05/30/us/politics/30ohio.html?pagewanted $=1 \&$ r=1 (March 24, 2011).

Zeleny, Jeff. 2010b. Obama’s Re-election Could Be Tied to Ohio. New York Times, October 28. http://www.nytimes.com/2010/10/29/us/politics/29ohio.html (March 24, 2011). 